\title{
A comparative study on the microbiological and chemical composition of cow milk from different
} locations in Madurai, Tamil Nadu

\author{
S. Lingathurai ${ }^{1}$, P. Vellathurai ${ }^{1}$, S. Ezil Vendan ${ }^{2}$ and A. Alwin Prem Anand ${ }^{2,3}$ \\ ${ }^{1}$ Biotechnology Division, The American College, Madurai- 625 002, India. \\ ${ }^{2}$ Research Centre for Biological Sciences (RCBS), Naesam Trust, Madurai-625 016, India. \\ ${ }^{3}$ Dept. Clinical Psychiatry \& Psychotherapy, Carl-Neuberg-Str. 1, 30625 Hannover, Hanover Med. School, Germany. \\ lings02@gmail.com
}

Abstract: Sixty samples of raw cow milk were collected from four different locations in Madurai for their microbiological and chemical compositions analysis. The average levels of major chemical components were: fat $(6.14 \%)$, crude protein $(3.77 \%)$, lactose $(4.25 \%)$, total solids $(18.10 \%)$ and ash $(0.80 \%)$. Microbiological enumeration revealed for the counts of total mesophilic aerobic bacteria, $5.84 \mathrm{log} \mathrm{cfu} / \mathrm{ml}$; bacterial endospores, $2.37 \mathrm{log} \mathrm{cfu} / \mathrm{ml}$; lactic acid bacteria, $4.46 \mathrm{log} \mathrm{cfu} / \mathrm{ml}$; coliforms, $2.76 \mathrm{log} \mathrm{cfu} / \mathrm{ml}$; Escherichia coli, $1.63 \mathrm{log} \mathrm{cfu} / \mathrm{ml}$ and Staphylococcus aureus, $1.92 \mathrm{log} \mathrm{cfu} / \mathrm{ml}$. Listeria spp. were below detection level in all of the samples. The microbiological quality of raw cow milk was judged marginal and indicates the need for improved hygienic standards.

Keywords: cow milk, chemical composition, microbiological quality, safety.

Introduction

Raw milk (RM) often contains microorganisms which may cause food borne diseases (Adesiyun et al., 1995: Steele et al., 1997; Headrick et al., 1998). Milk producers, processors, regulators and consumers share a common objective: the production and sale of safe, high quality milk and dairy products. Bacterial enumeration of bulk raw milk samples forms the basis of many dairy regulatory programs. The application of an accurate and efficient method to quantify the microbiological load of raw milk is essential to this objective. Historically, bacterial analysis of raw milk used the standard plate count (SPC) (IDF standard 100B, 1991; Houghtby et al., 1992), the plate loop count (PLC) (Thompson, 1960: Wright et al., 1970: IDF Standard 100B, 1991) and spiral plate count (SPL) (Gilchrist et al., 1973; Jarvis et al., 1977). The main goal of milk pasteurization or other heat treatment for cheese making is the elimination of pathogens, which may be present in milk. Apart from post- pasteurization contamination, the growth of milk pathogens depends strongly on the type of dairy technology (Grappin et al., 1987).

Pathogens that have been involved in food borne outbreaks associated with the consumption of milk include Listeria monocytogenes, Salmonella spp., Escherichia coli and Staphylococcus aureus. The presence of these pathogenic bacteria in milk emerged major public health concerns, especially for these individuals (Ryser, 1998).

China is the largest producer of milk; with both buffalo herds and buffalo milk production listed third Research article CIndian Society for Education and Environment (iSee) world wide in 2004 after those of India and Pakistan (FAO, 2004). In Tamil Nadu as per the $126^{\text {th }}$ livestock and poultry census 2000 the total cattle population is 93.63 lakhs, which accounts for $35.8 \%$ of the total livestock population in the country. The milk production in Tamil Nadu has increased tremendously over the past 20 years. From only 1.74 million tones in 1981, it has risen to 5 million tones in 2001. This has resulted in increase in per capita availability of milk to $219 \mathrm{gm}$ per day, which is very close to the Indian Medical Council Research (ICMR) recommendation of $220 \mathrm{~g}$ per day (TNMPFL, 2000). Fresh milk drawn from a healthy cow normally contains a low microbial load (less than $1000 \mathrm{ml}^{-1}$ ), but the loads may increase up to 100 fold or more once it is stored for sometimes at normal temperatures (Richter et al., 1992).

The objective of this study is therefore, to investigate the occurrence and load of microorganisms in cow milk with special reference to food borne pathogens. The results obtained serve as baseline data will be useful in future studies dealing with pathways of contamination and in the development of HACCP systems for hygienic processing of raw cow milk. The study also presents information on physiochemical parameters such as total solids, crude protein, lactose and fat content to enable an appreciation of the nutritional value of raw cow milk.

Materials \& Methods:

Samples of cow milk were obtained from Madurai district. Milking was done manually twice a day at $7.00 \mathrm{am}$ and $5.00 \mathrm{pm}$. A total 60 samples of raw cow milk were collected at four locations (North [Samayanallur], East [Thirumangalam], West [Oormechikulam] and South [Survayar Coloney]). At each location, samples of approximately $500 \mathrm{ml}$ were taken aseptically from the bulk milk container into sterile glass bottles. The milk was collected within $15 \mathrm{~min}$ of milking at ambient temperatures, kept on ice during $\approx 2 \mathrm{~h}$ transport and was analyzed immediately after arrival at the laboratory (Biotechnology Laboratory, The American College).

Chemical analysis

Fat content: Fat content and crude protein were determined by the Babcock and Kjeldahl methods, respectively.

Lactose: Lactose was determined by colorimetric method according to the Chinese standard method (GB/T 16285-1996). 
Total solids: Total solids were determined by conventional over drying $\left(60^{\circ} \mathrm{C}\right.$ for $2-3 \mathrm{~h}$ then $100^{\circ} \mathrm{C}$ for $6 \mathrm{~h})$ of $5 \mathrm{~g}$ milk samples.

$\mathrm{pH}$ : The $\mathrm{pH}$ was measured using a digital $\mathrm{pH}$ meter $(\mathrm{pH}$ 510 micro processor $\mathrm{pH}$ meter, Cyberscan, Italy): calibration was done with buffers of $\mathrm{pH} 4.00$ and $\mathrm{pH}$ 6.80.

Ash: A $10 \mathrm{~g}$ sample was evaporated in a water bath and then heated in a muffle furnace at $55^{\circ} \mathrm{C}$ for $3 \mathrm{~h}$, until the ash residue remained.

\section{Microbiological analysis}

Sample treatment: Representative $20 \mathrm{~g}$ portions were aseptically weighed, mixed with $180 \mathrm{ml}$ peptone saline $(0.1 \%$ neutral peptone, $0.9 \% \mathrm{NaCl})$, and homogenized by shaking. Subsequent decimal dilutions were prepared with the same diluents, and in all cases duplicate-counting plates were prepared of appropriate dilutions.

Total count of mesophilic aerobic bacteria (TC): TC was enumerated according to Chinese standard method GB/T 4782.2-2003, in pour plates of plate count agar (Hi Media, India), after incubation at $37^{\circ} \mathrm{C}$ for 2 days.

Bacterial endospores (BS): Raw cow milk samples were pasteurized $\left(80^{\circ} \mathrm{C}\right.$ for $\left.10 \mathrm{~min}\right)$ and $\mathrm{BS}$ was enumerated in pour-plates of PCA, after incubation at $37^{\circ} \mathrm{C}$ for $2 \mathrm{~d}$.

Lactic acid bacteria ( $L A B)$ : $L A B$ was enumerated according to Chinese Standard method GB/T4789.352003, in pour-plates of de Man, Rogosa and Sharpe medium (MRS, Merck, Germany), after incubation at $37^{\circ} \mathrm{C}$ for 3 days.

Coliform bacteria: Coliforms were enumerated using $3 \mathrm{M}$ petrifilm E. coli Coliform plates (3M, USA) after incubation at $37^{\circ} \mathrm{C}$ for $1 \mathrm{~d}$, and $E$. colifor $2 \mathrm{~d}$.

Staphyloccus aureus: $S$. aureus were enumerated using $3 \mathrm{M}$ petrifilm staph express count plate and disk (3M, USA). After incubation at $37^{\circ} \mathrm{C}$ for $1 \mathrm{~d}$, red-violet colonies on the plate were counted and presumed $S$. aureus colonies (having pink zones) were confirmed using the staph express disk after incubation at $37^{\circ} \mathrm{C}$ for $3 \mathrm{~h}$.

\section{Statistical analysis}

All microbial counts were converted to the base -10 logarithm of the number of colony forming units per $\mathrm{ml}$ of raw cow milk samples (log cfu/ml), and from these
Vol.2 No 2 (Feb. 2009)

ISSN: 0974- 6846 means and their standard deviations were calculated. Data were analyzed using analysis of variance (ANOVA) through the general linear models (GLM) procedure of the statistical analysis system software (SPSS version-11.5, 2003). Least significant differences were used to separate means at $p<0.05$

\section{Results and discussion}

\section{Chemical analysis}

Results obtained from the chemical analysis of raw cow milk are presented in Table1. Cow milk had lower crude protein, fat, lactose and total solid contents than those reported for milk (Fundora et al., 2001; Landmark et al., 2003). The average fat $(6.14 \pm 1.17 \% \mathrm{v} / \mathrm{v})$ and lactose $(4.25 \pm 0.40 \mathrm{w} / \mathrm{w})$ contents were slightly higher than those reported by Najdenova and Dimitrov (2003), but lower than found by Supino et al., (2004). The average crude protein $(3.77 \pm 0.40 \mathrm{w} / \mathrm{w})$, ash $(0.80 \pm 0.05$ $\mathrm{w} / \mathrm{w})$, and total solids $(18.10 \pm 1.40 \mathrm{w} / \mathrm{w})$ content and the average $\mathrm{pH}(6.44 \pm 0.25)$ of raw milk were similar to values reported elsewhere (Han \& Ding, 1994; Fundora et al., 2001).

Chemical composition data were studied by analysis of variance. Total solids, fat, crude protein, and ash of southern cow milk sample were significantly higher $(p<0.05)$ than those of northern and western regions. The lactose content of northern was significantly higher $(p<0.05)$ than those of other milk. It is not difficult to see that the total solid, fat, crude protein and ash content of the southern milk samples were higher than the values of western but lower those of southern.

Our findings are in agreement with those of (Zhang et al., 2004) who reported that the total solids, protein, fat, lactose, ash and non-fat solids content of south were higher than those of pure western, but lower than the southern. This ranking was to be expected: considering that the mixed southern milk has higher nutrient levels than the western milk (Han \& Ding, 1994; Amerjit \& Tshihiko, 2003), the milk composition of the southern is expected in between that of milk from southern milk.

Similar as for raw cow milk (Landmark et al., 2003), in addition to the type of breeds, other factors such as forage, feeding systems, milking frequency, milking method, seasonal changes and lactation period will exert an effect on the physio chemical parameters w milk in Madurai district

\begin{tabular}{|c|c|c|c|c|c|c|}
\hline Region & $\begin{array}{c}\text { Fat } \\
(\% \mathrm{v} / \mathrm{v})\end{array}$ & $\begin{array}{c}\text { Protein } \\
(\% \mathrm{w} / \mathrm{w})\end{array}$ & $\begin{array}{c}\text { Lactose } \\
(\% \mathrm{w} / \mathrm{w})\end{array}$ & $\begin{array}{c}\text { Total Solids } \\
(\% \mathrm{w} / \mathrm{w})\end{array}$ & $\mathrm{pH}$ & Ash (\%w/w) \\
\hline North $(\mathrm{n}=15)$ & $5.57 \pm 1.21^{\mathrm{\prime}} \mathrm{a}$ & $3.67 \pm 0.43^{\mathrm{a}}$ & $4.22 \pm 0.21^{\mathrm{a}}$ & $19.61 \pm 1.11^{\mathrm{a}}$ & $6.60 \pm 0.14^{\mathrm{ab}}$ & $0.83 \pm 0.03^{\mathrm{a}}$ \\
\hline West $(\mathrm{n}=15)$ & $5.53 \pm 1.28^{\mathrm{a}}$ & $3.69 \pm 0.20^{\mathrm{a}}$ & $4.47 \pm 0.41^{\mathrm{b}}$ & $18.45 \pm 1.24^{\mathrm{a}}$ & $6.45 \pm 0.33^{\mathrm{b}}$ & $0.79 \pm 0.06^{\mathrm{a}}$ \\
\hline East $(\mathrm{n}=15)$ & $6.56 \pm 0.90^{\mathrm{a}}$ & $4.01 \pm 0.53^{\mathrm{b}}$ & $3.71 \pm 0.65^{\mathrm{b}}$ & $17.25 \pm 1.31^{\mathrm{ab}}$ & $6.36 \pm 0.28^{\mathrm{b}}$ & $0.78 \pm 0.04^{\mathrm{ab}}$ \\
\hline South $(\mathrm{n}=15)$ & $6.90 \pm 1.30^{\mathrm{ab}}$ & $3.71 \pm 0.45^{\mathrm{bc}}$ & $4.60 \pm 0.35^{\mathrm{b}}$ & $17.11 \pm 1.96^{\mathrm{b}}$ & $6.36 \pm 0.26^{\mathrm{ab}}$ & $0.83 \pm 0.07^{\mathrm{b}}$ \\
\hline Average & $6.14 \pm 1.17$ & $3.77 \pm 0.40$ & $4.25 \pm 0.40$ & $18.10 \pm 1.40$ & $6.44 \pm 0.25$ & $0.80 \pm 0.05$ \\
\hline
\end{tabular}

${ }^{\star}$ Means $\pm S D ;{ }^{a b c}$ Means bearing different superscripts in the same column differ significantly $(p<0.005)$

Research article

(CIndian Society for Education and Environment (iSee)
"Milk quality"

http://www.indjst.org
Lingathurai et al. Indian J.Sci.Technol. 
Table 2. Microbiological loads of cow milk (log cfu/ml) in Madurai district

\begin{tabular}{|c|c|c|c|c|c|c|}
\hline Region & TC & BS & LAB & Coliforms & E. coli & S. aureus \\
\hline North $(\mathrm{n}=15)$ & $5.17 \pm 0.46^{\mathrm{a}}$ & $3.08 \pm 0.11^{\mathrm{a}}$ & $4.54 \pm 0.64^{\mathrm{a}}$ & $2.41 \pm 0.21^{\mathrm{a}}$ & $1.63 \pm 0.13^{\mathrm{a}}$ & $2.15 \pm 0.53 \mathrm{a}$ \\
\hline West $(\mathrm{n}=15)$ & $6.40 \pm 0.31^{\mathrm{b}}$ & $2.44 \pm 0.21^{\mathrm{b}}$ & $5.03 \pm 0.31^{\mathrm{b}}$ & $3.36 \pm 0.08^{\mathrm{a}}$ & $1.65 \pm 0.41^{\mathrm{b}}$ & $2.34 \pm 0.47^{\mathrm{a}}$ \\
\hline East $(\mathrm{n}=15)$ & $5.45 \pm 0.34^{\mathrm{b}}$ & $1.61 \pm 0.26^{\mathrm{b}}$ & $3.69 \pm 0.20^{\mathrm{ab}}$ & $2.21 \pm 0.29^{\mathrm{a}}$ & $1.46 \pm 0.17^{\mathrm{b}}$ & $1.40 \pm 0.72^{\mathrm{b}}$ \\
\hline South $(\mathrm{n}=15)$ & $6.37 \pm 0.14^{\mathrm{b}}$ & $2.35 \pm 0.41^{\mathrm{a}}$ & $4.61 \pm 0.61^{\mathrm{ab}}$ & $3.09 \pm 0.11^{\mathrm{a}}$ & $1.89 \pm 0.09^{\mathrm{b}}$ & $1.81 \pm 0.17^{\mathrm{C}}$ \\
\hline Average & $5.84 \pm 0.31$ & $2.37 \pm 0.27$ & $4.46 \pm 0.44$ & $2.76 \pm 0.18$ & $1.63 \pm 0.20$ & $1.92 \pm 0.47$ \\
\hline
\end{tabular}

Table 3. Microflora of 60 samples of cow milk in Madurai district

Type of $\quad \%$ of samples with log N cfu /ml

\begin{tabular}{|c|c|c|c|c|c|c|c|}
\hline \multirow[b]{2}{*}{ microorganism } & \multicolumn{7}{|c|}{ } \\
\hline & $<1$ & $1-2$ & $2-3$ & $3-4$ & $4-5$ & $5-6$ & $6-7$ \\
\hline TC & & & & & 10 & 74 & 16 \\
\hline $\mathrm{LAB}$ & & 12 & 35 & 27 & 18 & 6 & \\
\hline BS & & & 3 & 67 & 25 & 5 & \\
\hline Coliforms & & 7 & 71 & 14 & 8 & & \\
\hline E. coli & 18 & 34 & 44 & 4 & & & \\
\hline S. aureus & 21 & 29 & 40 & 10 & & & \\
\hline Listeria spp & 100 & & & & & & \\
\hline
\end{tabular}

TC- Total count of aerobic bacteria; $L A B$ - Lactic acid bacteria, $B S$ - bacterial endospores.

\section{Microbiological analysis.}

The microflora of raw cow milk is presented in Tables 2 \& 3 . Differences among milks from different regions of cow raw milk were studied by analysis of variance (Table 2$)$ of all regions. The highest $(p<0.05)$ average loads of TC, LAB and coliforms were observed in northern. No significant differences were observed with respect to the average counts of $E$. coli.

Raw milk contained an average TC of $5.84 \mathrm{log} \mathrm{cfu} / \mathrm{ml}$. It is a high count of TC and should be due to inadequate sanitary conditions during milking, collection and transport. Raw cow milk in Italy (Supino et al., 2004) had total bacterial counts of $5.23 \mathrm{log} \mathrm{cfu} / \mathrm{ml}$, which is of the same as our data. LAB constituted a major part of the microflora with an average $4.46 \mathrm{log} \mathrm{cfu} / \mathrm{ml}$. Boycheva et al., (2002) observed that LAB and psychrotrophs predominated in Bugarian buffalo milk. As the result indicates relatively high numbers of $L A B$, it may cause undesirable fermentative acidification of raw milk. So effective measures should be taken to avoid this kind of spoilage.

The average count of bacterial endospores was $2.37 \mathrm{log} \mathrm{cfu} / \mathrm{ml}$; these usually originate from the soil, manure, and forages (Zhou, 1998). Although only 9\% of the samples exceeded the tolerated level of $10^{4}$ $\mathrm{cfu} / \mathrm{ml}$ (Table 3 ), spores however pose a potential threat for the quality of buffalo milk products, since they might survive pasteurization and other heat treatments (Te geffel, 2003).

The average load of $S$. aureus was $1.92 \mathrm{log} \mathrm{cfu} / \mathrm{ml}$. Fook et al.,(2004) reported considerably higher levels having $4.2 \log \mathrm{cfu} / \mathrm{ml}$. since $S$. aureus is potentially hazardous at $>10^{4} \mathrm{cfu} / \mathrm{ml}$ (Han et al.,2005), all cow milk samples were within an acceptable level. However, since $79 \%$ samples contained $S$. aureus, it must be prevented to avoid potential risk. The presence of Listeria spp. was not detected in any samples. The average levels of coliform bacteria and E. coli were 2.76 and $1.63 \mathrm{log} \mathrm{cfu} / \mathrm{ml}$ respectively (Table 2).

These counts were higher than those reported by Desmasures et al.,(1997), who reported that $84 \%$ of samples of French cow milk had coliform counts $<100$ $\mathrm{cfu} / \mathrm{ml}$ and $80 \%$ had $E$. coli counts $\leq 10 \mathrm{cfu} / \mathrm{ml}$. E. coli may be considered an indicator microorganism of faecal contamination and other entric pathogens. Its occurrence in milk may originate from machines, manual milking, handling, and inferior quality of water (Fook et al., 2004).

Conclusion

The chemical composition of raw cow milk indicates that it is a rich source of nutrients and thus offers excellent opportunities for the development of local dairy industry and to meet the public need for nutrition. The microbiological quality was only marginally acceptable with respect to the total bacteria count. Nevertheless, the presence of pathogenic and indicator bacteria, such as $E$. coli, coliforms and $S$. aureus indicate that to the growth of these organisms may lead to a hazard against public health. Therefore practice and regulations, such as on-site pasteurization and implementation of HACCP following established standards, should be introduced to facilitate the production of cow milk of high quality and safety.

\section{References}

1. Adesiyun AA, Webb $L$ and Rahman $S$ (1995) Microbiological quality of raw cow milk at collection centers in Trinidad, J. Food Production. 58 (4) 448.

2. Amerjit SN and Toshihiko N (2003) Role of buffalo the socioeconomic development of rural Asia: Current status and future prospects. Animal Sci. J. 74, 443-445.

3. Boycheva S, Dimitrov T, Tsankova M and Llier T (2002) Investigation on microflora of buffalo milk. Bugarian J. Agri. Sci. 8, 279-282.
Research article

CIndian Society for Education and Environment (iSee)
"Milk quality"

http://www.indjst.org
Lingathurai et al. Indian J.Sci.Technol. 
4. Desmasures N, Bazin F and Gueguen M (1997) Microbiological composition of raw milk farms in the camembert region of Normandy. J. Appl. Microbiol. 88, 53-58.

5. FAO (2004) Available from http://www.fao.org/docrep/006/J2518e/J2518e 12.htm

6. Fook YC, Aminah A and Mohd KA (2004) Bacteriological quality and safety of raw milk in Malaysia, Food Microbiol. 21, 535-541.

7. Fundora O, Gonzalez ME, Lezcano O, Montejo A, Pompa N and Enriauezo AV (2001) A comparative study of milk composition and stability of Murrah river buffaloes and Holstein cows grazing star grass. Cuba J. Agri. Sci. 35, 219-222.

8. Gilchrist JE, Cambell JE, Donelly CB, Peeler JT and Delany JM (1973) Spiral plate method for bacterial determination. Appl. Microbiol. 25(2), 244-252.

9. Grappin R, Dasen A and Favennec P (1985) Numeration automatiquie et rapide des bacterias du lait cru d l'aide. Bacto-Scan. Lait. 65 (649-650), 123-147.

10. Han BZ, Sesenna B, Beumer RR and Nout MJR (2005) Behaviour of Staphylococcus aureus during sufu production at laboratory scale. Food Control. 16, 243-247.

11. Han G and Ding QB (1994) A physiochemical study on buffalo milk in China. J. South China Agri. Univ., 15(4), 92-97 (in Chinese).

12. Headrick $\mathrm{ML}$, Korangy $\mathrm{S}$, Bean $\mathrm{NH}$, Angulo $\mathrm{FJ}$, Altekruse SF, Potter ME and Klontz KC (1998) The epidemiology of raw milk associated food borne disease out breaks reported in the United States, 1973 through 1992. American J. Public Health. 88 (8), 1219-1221.

13. Headrick, M. L., Korangy, S., Bean, N. H., Angulo, F. J., Altekruse, S. F., Potter, M. E., and Klontz, K. C., (1998). The epidemiology of raw milk associated food borne disease out breaks reported in the United States, 1973 through 1992. American Journal of Public Health, 88 (8), 1219-1221.

14. Houghtby GA, Marturin LJ, Koenig EK and Messer JW (1992) Microbiological count methods. In standered methods for the examination of dairy products er. R.T mardhall, $16^{\text {th }}$ edn. Pp213-246. APHA: Washington

15. IDF standard 100B (1991) Liquid milk enumeration of microorganism's colony count techniques at $30^{\circ} \mathrm{C}$.

16. Jarvis B, Lach VH and Wood JM (1997) Evaluation of spiral plate maker for enumeration of microorganisms in foods. J. Appl. Bacteriol. 43, 149157.
17. Landmark-Mansson $\mathrm{H}$, Fonden $\mathrm{R}$ and Petterson HE (2003) Composition of Swedish dairy milk. Intnl. Dairy J. 13, 409-425.

18. Najdenova N and Dimitrov T (2003) Technological qualities of buffalo milk from the Bulgarian murrah breed for production of Bulgarian yoghurt. J. Animal Sci. 40 (5), 33-35.

19. Richter RL, Ledford RA, Murphy SC (1992) Milk and milk products. In Vanderzant, C., Splittstoessor, D. F. (Eds.). Compendium of methods for the microbiological examination of foods, $3^{\text {rd }}$ edition. American Public Health Association, Washington, DC, pp:837-838.

20. Ryser ET (1998) Public health concerns. In Marth, E, H., Steele, J. L., (Eds.), Appl. Dairy Microbiol. Marcel decker, inc., New York, pp: 263-403.

21. Steele ML, Mcnab WB, Poppe C, Graffiths MW, Chen S, Degrandis SA, Fruhner LC, Larkin CA, Lynch JA and Odumeru JA (1997) Survey of Ontario bulk tank milk for food borne pathogens. J. Food Prot. 60 (11) 1341-1346.

22. Suman CL, Sexena MM, Pandey HS, Dubey PC, Rajendra S and Sanyal MK (1998) Some factors affecting milk constituents yield of Murrah buffalo. Indian Vet. J., 75(2), 176-177.

23. Supino MT, Gallo M, Capo G, Morena. C, Durnate $G$ and Galiero G (2004) Buffalo milk produced in the province of salerno: Evaluation of sanitary and product parameters Bubalus bubalis. CAB Abs.10, 22-26.

24. Te giffel MC (2003) Good hygienic practice in milk processing. In g. Smit (Edn.), Dairy processing, improving quality ( $\mathrm{pp}, 68-80$ ) boca ration: CRC press.

25. Thompson DI (1960) A plate maker loop method for determine viable counts of raw milk. Journal of Milk and Food Technology. 23, 167-171.

26. TNCMPF- Tamil Nadu Cooperative Milk Products Federation (2000), Final Report, South India.

27. Wright EO, Reinhold GW, Burmeister $L$ and Mellon J (1970) Prediction of standered plate loop count manufacturing grade raw milk from the plate loop count. J. Milk Food Technol. 33, 168-170.

28. Zhang CX, Yang BX, Tan T and Zhuge $Y$ (2004) Sustainable development of Chinese bufflo milk industry. China Dairy Industry. 11, 11-15. (In Chinese).

29. Zhou W (1998) High quality raw milk production, China Dairy Industry. 26 (1), 31-33 (In Chinese).
Research article

(CIndian Society for Education and Environment (iSee)
"Milk quality"

http://www.indjst.org
Lingathurai et al. Indian J.Sci.Technol. 